\title{
Food Policy Beyond Neo-Liberalism
}

\author{
Valeria Sodano \\ University Federico II of Naples, \\ Italy
}

\section{Introduction}

For millennia food has been one of the central elements around which human civilizations have evolved. In pre-capitalistic societies food-related activities were at the core of all the material, cultural and institutional structures which shaped social relations. Besides being the adherent factor of society, food has always been a weapon and an instrument of power. Along with the development of capitalism, food-related activities have become increasingly integrated into the economic sphere, which has gained importance with respect to the sociocultural and political spheres. Food has become nothing more than a commodity, its trade has become a way of wealth accumulation and the market, instead of self-production in peasant societies, has become its main way of procurement for urban dwellers and the workforce required by industrialization. The "domestication" of food habits and trade has been an important leverage for capital accumulation. As a matter of fact, as the literature on food regimes has clarified, different stages of capitalistic development have required different features of food governance.

This paper analyses the particular features of food governance under neoliberalism, considered the most recent stage of capitalistic accumulation. The main goal is to identify the political and theoretical constraints which seem to prevent food policy from becoming an effective tool for promoting a just and sustainable food system. A basic argument of this paper is that the analysis of the food case may give important insights for identifying the 'ideological' powers that have hitherto guided the neoliberal political-economic design. The discussion is organized as follows.

The first section describes the neoliberal global food system starting from the recent literature on food regimes and shows how it has so far been unable to achieve the goals of sustainability, hunger eradication and social justice.

The second section directly addresses the issue of food policy. It compares the future challenges facing the system with the neo-liberal strategies of interventions, demonstrating how neoliberal food policy is a useless weapon against the increasing food safety and security risks. Particular attention is paid to the issue of private governance.

The third section illustrates the main traits of food policy programs alternative to neoliberalism. The focus is on the concept of food sovereignty, which encompasses the concepts of food as a human right and sustainability. 
The last section, dealing with the obstacles faced by opponents to neoliberalism, analyzes the limits of the specific ethical and political theories endorsed by the standard economic model and shows the difficulties experimented by alternative approaches in drawing new theoretical paradigms. Given its theoretical scope, the paper does not however address the political obstacles arising from concrete political practices in real institutional contexts.

The main outcome of the paper is that, in order to overcome the neoliberal policies, one must enable processes of participatory democracy by appealing to the distinctive character of the human being, namely reflexive deliberation.

\section{The neoliberal food regime}

In order to uncover the peculiar traits of the neoliberal food policy it is important to explore the links between the development of the food system and capitalism itself. The history of food and food policy closely follows the history of the Industrial Revolution and of twentieth century capitalism. To understand how the international division of labor in agriculture as well as food policy depend strictly on processes of capitalistic accumulation, one can depart from the concept of food regime. According to this concept, developed within the world-system research strain, the organization of food production and distribution is explained better by political rather than economic factors. Friedman's basic definition of food regime is 'a rule-governed structure of production and consumption on a world scale' (Friedmann, 1993). A particular food regime is characterized by a hegemonic power which is able "to dictate the rules". Literature on food regime, inaugurated by Friedmann (Friedmann, 1987, 1993, 2004; Friedmann and McMichael, 1989) is anchored to the theories of world system and of regulation, and was first elaborated within the research field of international relations and international political economy. Currently it is an interdisciplinary approach, encompassing the fields of economics, history, politics, sociology and law.

So far, three food regimes have been described. In the first period, spanning between 1870 and 1914 and designated as "Settler-Colonial", Britain inaugurated the policy of "cheap food' for the industrial working class, based on the imports of basic grains and livestock from settler colonies. In this period the imposed mono-cultural agriculture, while feeding industrialization and capital accumulation in the mother countries, compromised food systems and ecological resources in colonies. In Africa and Latin America, many regions moved from a situation of food self-sufficiency to a situation of food scarcity and famine, paving the way for the successive food regime, the "Surplus" regime, between 1945 and 1973. In this period the Unites States, under the umbrella of food aid programs, invaded their informal empire of postcolonial states with their food surpluses, clutching them in the grip of the external debt. This was the effect of the high-level support that the US had to give to their enterprises in order to maintain an international economic hegemony by backing the value of the dollar to which other currencies were anchored in the Bretton Woods system. Moreover, at that time the profits of American companies that came from the favorable terms of trade with the Least Developed Countries (LDCs) were used to finance growth in Europe, itself a market for imported American products. Partly because of the changed scenario of international trade (with Europe emerging as an important food exporter), partly because of the end of the US monetary hegemony (and the associated world monetary stability), and partly because of the new corporate interests within the system (with 
corporations seeking new investments and market opportunities offered by trade liberalization and by the growing demand in emergent countries), the second food regime actually ends with the demise of Bretton Woods. Since then a third food regime has initiated which, notwithstanding its still blurred contours, may be termed neoliberal or corporate regime ${ }^{1}$.

The neoliberal food regime (sometimes also referred to as 'food from nowhere' regime or 'corporate' food regime, as reported by McMichael, 2009) is the product of neoliberalism, which has been shaping global economy over the last thirty years. The four credos of neoliberalism - deregulation, international trade liberalization, reduction of public expenditure and privatization - have produced a new international food order, characterized, inter alia, by: 1) a high level of consolidation at the manufacturer and retail level, with a dramatic rise of corporate power; 2) an international division of labor based on the organizational features of global food commodity chains, with the rise of export zones in the global south and the displacement of independent producers and small scale agriculture; 3) an increasing market differentiation, with low-quality mass products alongside with "high-tech/high quality" rich products; 4) bio-nano technologies and intellectual property rights as the new frontiers for profit extraction; 5) the accelerated depletion of natural resources, with a global food system increasingly dependent on oil and massively contributing to climate change (Garnett, 2008; Shiva, 2008).

The specific traits of the three food regimes are very different and in each of them food has had a different role in the economic as well in the political and socio-cultural sphere. This paper does not intend to review the concept and the history, and the related theoretical and political controversies, of food regime and therefore such differences are not explored. What is important here, in order to analyze the neoliberal food policy, is to highlight only the main common trait and the main difference between the neoliberal food regime and its predecessors. This will help to shed light on the core elements of the current economic and political dynamics within the world food system.

The red thread which unifies the three food regimes is the integration of the food production and consumption activities into the processes of industrialization and capitalistic accumulation. As stressed by McMichael (2009), "the food regime concept is not about food per se, but about the relations within which food is produced, and through which capitalism is produced and reproduced". Since the beginning of the first food regime (which coincides with the second industrial revolution, 1870-1914) the capitalistic development has entailed:

1. The commodification of food, that is to say, in current terminology, that food production and distribution have entered the formal sector of the economy (i.e. that regulated by formal markets, whose sales and turnovers compose the GNP). Food markets have replaced self-sustained peasant communities, where production systems are governed by an array of institutions which range from authoritative feudal and family organizations to gift and community-based systems of reciprocal systems of exchange. In this way not only alternative ways of economic organization have been destroyed, but also entire cultures and societies.

${ }^{1}$ The debate on the identification and definition of the third food regime is reported by McMichael (2009). See also: Burch and Lawrence, 2009; Pechlaner and Otero, 2010. 
2. An increasing dependence of agriculture on other economic sectors, including the financial sector.

3. The international integration of agricultural systems and markets.

4. A pattern of technological innovations which have rendered the food sector not only increasingly dependent on non-renewable energy sources but also increasingly harmful to the environment.

Besides these similarities, there is a profound difference between the previous and the third food regimes. Unlike the previous food regimes, where the hegemonic powers were nation states (the UK first followed by the U.S.A.) in the third regime hegemonic power is exercised by the large TNCs which control the global food chains. In other words, with the rising of the neoliberal regime, there has been a shift from state to private food governance. That is not to say that in the first and second regimes state strategies did not accommodate the private interests of the capitalist ruling class. They did indeed but in an institutional framework where states and corporations still operated in two separate spheres, namely the political and the economic sphere, which remained separate even when the political sphere succumbed to corporate power. With neoliberalism, private interests no longer "capture" (Stigler, 1971) state regulation, but in fact they substitute the state by becoming themselves the regulators of the economy (and of society). The process through which this shift has occurred, widely described by literature on globalization and neoliberalism (Sassen , 1995, 2006; Strange, 1996; Hall, Biersteker, 2002), has relied at least on the following five concomitant factors which to an extent have had mutual knock-on effects: 1- the end of the Bretton Wood system and the deregulation/liberalization of capital markets, 2- the finacialization of the economy, spurred, inter alia, by the radical innovations in the financial sector (Strange, 1998); 3- the upsurge of The Chicago School of Economics as a dominant mainstream academic "credo", also contaminating politics and laws with its blind faith in the rational choice model (as witnessed by the public choice theory and the research field of law and economics.); 4- the new strategies of corporate internazionalization based on the organizational architecture of global supply (commodity/value) chains; 4- the demise of socialist economies and the integration of new powers, such as China, in the world capitalistic system; 5- the end, as far as international relations are concerned, of the Westphalian order, and the consequent weakening of the concept of state sovereignty.

Literature on food regime extensively describes the negative results of the long wave of inclusion of food in processes of capitalistic accumulation, such as chronic world hunger and poverty, the depletion of natural resources, the destruction of peasant cultures, the growing wealth inequality and social injustice. Obviously, a good deal of literature confutes this view and applauds the outstanding achievements of the Green Revolution and biotechnologies, international market integration and peasantry upgrading. This paper does not specifically enter into the debate concerning these two contrasting views (and does not even offer a brief overview of the debate), but nonetheless introduces new arguments in favor of the view of food regime literature. The next section demonstrates, starting from the list of the main malfunctions of the current world food system, how an effective policy aimed at improving the system should repudiate the mechanisms that keep food production and consumption in the clutches of capitalist system. 


\section{The unsustainable neoliberal food policy}

As a generally intended term food policy refers to the two fields of intervention of food safety and food security. Moreover, a third field may be added concerning the control of the environmental impact of food production and distribution; this component may be called food sustainability. As an institutionalized field of state intervention food policy emerged at the beginning of the third food regime. The term food security was coined for the first time following the First World Food Conference in 1974 in Rome. The term food safety was used first in the United States in 1977 when naming the Food Safety and Inspection Service (FSIS). ${ }^{2}$ During the previous food regimes the only institutionalized field of public intervention was agricultural policy, which was part of the general economic development policy, and was often subordinated to industrial policy. The first World Food Summit was convened under the emotional boost of the global economic crisis, -consequent to the concomitant food, financial and oil crisis-, of the 1971-73. Nevertheless, it was also the culmination of decades of protests (summarized by the demand for a New International Economic Order) expressed by the "third world" countries due to the exploitation of their natural resources and the consequent persistent hunger and poverty they faced.

In 1974, governments attending the World Food Conference had proclaimed that "every man, woman and child has the inalienable right to be free from hunger and malnutrition in order to develop their physical and mental faculties." This statement reflects the prevalent politically economic view of the time, which, under the general label of "welfare state", endorsed an active role of states in the economy in order to fulfill their commitment to uphold human rights and promote social justice. In 1974 the declared goal of governments was to completely eradicate hunger on a world scale. Two decades later, when the neoliberal wind had already passed into oblivion the policy attitudes of the embedded liberalism, the Rome Declaration, at the 1996 World Food Summit, set the far less ambitious target of reducing by half the number of undernourished people by no later than the year 2015.

Therefore, as a matter of fact, food policy so far has suffered from a severe internal inconsistency: while its goals were set in the political era antecedent neo-liberalism, its instruments have been developed together with the consolidation of neoliberal ideology.

Neoliberalism represents a new particular political economic approach in liberal systems of modern capitalist societies, which has replaced the previous approach of embedded liberalism (Harvey, 2005). According to embedded liberalism, to which the experience of welfare states in the thirty years 1950-1970 has been linked, the economic sphere is embedded in the social and political spheres, and the state has the mandate to intervene in the economy with regard to a variety of goals beyond the allocative efficiency; such as distributional and political goals. On the contrary, according to neoliberalism, the economic sphere is independent from the social and political one and states ought to abstain from intervening in the economy, allowing individuals to participate in free and self-regulating markets. In the case of food policy, these two perspectives lead to a very different choice of

\footnotetext{
2 The concept of food safety has been incorporated in the more complex definition adopted at the 1996 World Food Summit: "Food security, at the individual, household, national, regional and global levels [is achieved] when all people, at all times, have physical and economic access to sufficient, safe and nutritious food to meet their dietary needs and food preferences for an active and healthy life".
} 
goals and instruments. Table 1 confronts food policies in the two cases of embedded liberalism and neoliberalism. In the first column, the main food policy goals are listed according to the two possible rationales for intervention: the sole economic rationale, concerning the improvement of allocative efficiency through the correction of market failures (such as non competitive markets, externalities, public goods and information problems), and the ethical/political rationale, concerning the accomplishment of social justice and human rights. In the second and third columns, the main policy instruments deployed in case of embedded liberalism and neoliberalism are listed. There are two major differences between the two political views.

The first difference is that while embedded liberalism is consistent with both the economic and the political/ethical rationales, neoliberalism only accepts the economic rationale. In other words, while embedded liberalism awards distributive and social goals a prominent place in the food policy agenda, the only goal accepted by neoliberalism is economic efficiency. An important consequence is that neoliberalism does not foresee any form of intervention in order to uphold individuals' rights to adequate and safe food. With respect to food security, the rationale for intervention is ethical and political rather than economic. Ensuring access to food for poor people means carrying out policies of income redistribution, which respond to objectives of social justice rather than of economic efficiency; it also means considering food to be a human right, which has to be upheld by governments through public commitment. However, it is worth noticing that the goal of food security is still pursued under neoliberalism, but the idea is that keeping markets free from any form of intervention will boost economic development and, through a trickledown process, will eventually benefit hungry people; hence food security is considered to be the "natural" outcome of the economic development assured by a system of free markets.

The second difference is that in the case of market failures, while neoliberalism only acknowledges market-based instruments, embedded neoliberalism strongly relies also on command-and-control policies. Many problems of food safety and sustainability can be modelled in terms of market failures. In the case of food safety an adequate risk prevention may be considered as a public good, for which properties of non rivalry and non excludability prevent the private sector from providing the efficient supply. Also imperfect information applies, when the low food risk is seen as a quality attribute exhibiting the character of a credence good (the typical example is the presence of chemicals and phytosanitary products' residual substances). Externalities are the main concern in the case of sustainability goals; moreover, prevention of negative environment impacts may be considered as a public good; for instance, reducing green house gas (GHG) emissions is a public good, which firms do not provide unless with direct state intervention. As summarized in table 1, embedded liberalism tackles all these problems with a large set of instruments, including all types of state direct and command-and-control interventions, such as standards, regulation and state participation in economic activities. On the contrary neoliberalism only deploys market-based instruments, such as taxes and incentives, privatization and self-regulation (Backer, 2008; Pariotti, 2009). In fact, neoliberal ideology endorses a system of free markets and free trade where the only acceptable reason for state regulation is to safeguard commercial liberty and private property. Accordingly, it stresses that: problems of public goods may be solved through the Coase theorem (and hence through privatization); food safety can be fulfilled through self regulation and SCR; food security is the "natural" outcome of the economic development assured by a system of free 
markets; state failures are more dangerous than market failures, which tend to be selfcorrecting as long as the free competitive process is not disturbed.

\begin{tabular}{|c|c|c|}
\hline \multirow[b]{2}{*}{ Food policy goals } & \multicolumn{2}{|l|}{ Food policy instruments } \\
\hline & $\begin{array}{l}\text { Embedded liberalism } \\
\text { (the economic sphere } \\
\text { dependent on social and } \\
\text { political sphere) }\end{array}$ & $\begin{array}{l}\text { Neoliberalism } \\
\text { (economization of social and } \\
\text { political sphere) }\end{array}$ \\
\hline \multicolumn{3}{|l|}{ The economic rationale } \\
\hline $\begin{array}{l}\text { Correcting market failures: non } \\
\text { competitive markets }\end{array}$ & $\begin{array}{l}\text { Competition policy (high } \\
\text { enforcement). }\end{array}$ & $\begin{array}{l}\text { Chicago school approach to } \\
\text { competition policy (low } \\
\text { enforcement) }\end{array}$ \\
\hline $\begin{array}{l}\text { Correcting market failure: } \\
\text { negative externalities (limiting } \\
\text { the environmental impact of } \\
\text { food production and } \\
\text { distribution, such as pollution, } \\
\text { global warming, and non } \\
\text { renewable resource depletion) }\end{array}$ & $\begin{array}{l}\text { Command and control } \\
\text { instruments (standards } \\
\text { and regulation) } \\
\text { Market based } \\
\text { instruments (taxes, } \\
\text { subsidies, and economic } \\
\text { incentives) }\end{array}$ & $\begin{array}{l}\text { Market based instruments, } \\
\text { according preference to } \\
\text { economic incentives with } \\
\text { respect to taxes (e.g. carbon } \\
\text { emission trading preferred to } \\
\text { carbon tax) } \\
\text { Self regulation } \\
\text { Private governance } \\
\text { CSR }\end{array}$ \\
\hline $\begin{array}{l}\text { Correcting Market failure: } \\
\text { public goods (food safety and } \\
\text { climate change mitigation as } \\
\text { examples of public goods) }\end{array}$ & $\begin{array}{l}\text { Command and control } \\
\text { (standards and } \\
\text { regulation) } \\
\text { Market based } \\
\text { instruments (taxes and } \\
\text { subsidies) } \\
\text { State as a direct provider } \\
\text { of public goods }\end{array}$ & $\begin{array}{l}\text { Market based instruments } \\
\text { Privatization } \\
\text { SCR } \\
\text { Private governance } \\
\end{array}$ \\
\hline $\begin{array}{l}\text { Correcting market failure: } \\
\text { informative imperfection (as in } \\
\text { the case of credence goods and } \\
\text { food risk) }\end{array}$ & $\begin{array}{l}\text { Regulation } \\
\text { Disclosure } \\
\text { Public information }\end{array}$ & $\begin{array}{l}\text { Self-regulation } \\
\text { Private governance }\end{array}$ \\
\hline \multicolumn{3}{|l|}{ Ethical and political rationale } \\
\hline $\begin{array}{l}\text { Assuring access to safe food to } \\
\text { poor people. Food as a human } \\
\text { rights } \\
\text { Food safety and food security } \\
\text { policies as a matter of social } \\
\text { justice }\end{array}$ & $\begin{array}{l}\text { Regulation } \\
\text { Fiscal measures } \\
\text { Direct market } \\
\text { interventions } \\
\text { Upholding human rights } \\
\text { (the economic dimension } \\
\text { overshadowed by } \\
\text { political and social } \\
\text { dimensions) }\end{array}$ & No intervention \\
\hline
\end{tabular}

Table 1. Food policy instruments in the neoliberal food regime 
Thirty years of neoliberal food policy seem not to have been successful in achieving the most part of food policy goals. Currently the food system at global level proves inadequate to meet people's needs and to ensure the preservation of natural resources and the environment. Health emergencies related to obesity and hunger pose serious challenges to people's lives, while the increasing food industrialization and globalization destroy the environment and natural resources apace. Figures in table 2 briefly synthesize "food failures" of current times, which pose serious challenges for the future food policy.

\begin{tabular}{|c|c|}
\hline Food security & $\begin{array}{l}\text { The number of people lacking access to the minimum diet has risen from } 824 \\
\text { million in } 1990 \text { to } 925 \text { million in } 2010 \text {. }\end{array}$ \\
\hline Global warming & $\begin{array}{l}\text { Considering also emissions by indirect activities associated with food } \\
\text { production and distribution (such as home storage and refrigerators, waste } \\
\text { disposal, transportation by final consumers and so on) the global food system } \\
\text { is accountable for nearly } 50 \% \text { of total world GHG emissions (Grain, 2009). } \\
\text { Climate change threatens food production through desertification, water } \\
\text { shortages, yield decreases. }\end{array}$ \\
\hline Energy & $\begin{array}{l}\text { In the future oil shortages may threaten food availability. It takes more than } \\
400 \text { gallons of oil to feed one person for a year in the USA. In terms of energy } \\
\text { conversion this food production system means that it takes three calories of } \\
\text { energy for every single calorie of edible food produced on average. In the } \\
\text { case of grain-fed beef it takes } 35 \text { calories of energy for every one calorie of } \\
\text { beef. Oil shortage threatens food security also through the increasing use of } \\
\text { arable land for bio fuel production. }\end{array}$ \\
\hline $\begin{array}{l}\text { Land depletion } \\
\text { and land grabbing }\end{array}$ & $\begin{array}{l}\text { The amount of arable land per capita is steadily decreasing. It has almost } \\
\text { halved since } 1960 \text {. After the } 2008 \text { food crisis rich countries and TNCs have } \\
\text { been buying large swathes of land, mainly offered by corrupted governments } \\
\text { and elites in developing countries. }\end{array}$ \\
\hline Water scarcity & $\begin{array}{l}\text { Agriculture accounts for } 70 \% \text { of global fresh water use. Almost a billion } \\
\text { people live in countries chronically short of water. By } 2030 \text { demand for water } \\
\text { is expected to increase by } 30 \% \text {. }\end{array}$ \\
\hline Food safety & $\begin{array}{l}\text { Unsafe food causes many acute and life-long diseases, ranging from } \\
\text { diarrhoeal diseases to various forms of cancer. WHO estimates that } \\
\text { foodborne and waterborne diarrhoeal diseases taken together kill about } 2.2 \\
\text { million people annually, } 1.9 \text { million of them children. }\end{array}$ \\
\hline $\begin{array}{l}\text { Competition and } \\
\text { power } \\
\text { asymmetries in } \\
\text { the food chain }\end{array}$ & $\begin{array}{l}\text { There are evident imbalances of power among the different stages of the } \\
\text { world food chain. About } 7 \text { billion consumers and } 1.5 \text { farmers are squeezed by } \\
\text { no more than } 500 \text { companies -retailers, food companies, traders and } \\
\text { processors- who control } 70 \% \text { of the world food market. Only three companies } \\
\text { (Cargill, Bunge and ADM) account for } 90 \% \text { of the global grain trade. Four } \\
\text { firms (Dupont, Monsanto, Syngenta and Limagrain) control over } 50 \% \text { of seed } \\
\text { industry. Large companies in the food system are now expanding their power } \\
\text { by directly regulating the system, setting private standard and dictating } \\
\text { policy agendas to international organisms. }\end{array}$ \\
\hline Inequalities & $\begin{array}{l}\text { Hunger does not affect uniformly people in the world: it is concentrated in } \\
\text { developing countries, in rural area and among women. In other words } \\
\text { hunger is concentrated among poor people. Neoliberal globalization has } \\
\text { raised income inequalities, making poverty and hunger "incurable deseases". }\end{array}$ \\
\hline
\end{tabular}




\begin{tabular}{|l|l|}
\hline $\begin{array}{l}\text { Food loss and } \\
\text { waste }\end{array}$ & $\begin{array}{l}\text { Food waste and loss, i.e. food that is discarded or lost uneaten, annually } \\
\text { account for 1.3 billion tons of food, about one third of the global food } \\
\text { production (according to a 2011 estimate). Consumers' attitudes and retailers' } \\
\text { procurement and marketing policies are referred to as the main causes. }\end{array}$ \\
\hline $\begin{array}{l}\text { Malnutrition and } \\
\text { obesity }\end{array}$ & $\begin{array}{l}\text { Besides hunger malnutrition means over nutrition and obesity. Obesity is } \\
\text { associated with higher mortality rates for cardiovascular diseases and cancer. } \\
\text { In the United States obesity and overweight together are the second leading } \\
\text { cause of preventable death. Over the last twenty years obesity has also spread } \\
\text { in developing countries. World obesity epidemic has multiple causes, } \\
\text { nevertheless important recognized causes are poverty, low level of education, } \\
\text { children exposure to junk food advertising. }\end{array}$ \\
\hline
\end{tabular}

Table 2. The unsustainable neoliberal food regime

Over the last thirty years, food and agriculture have not been at the top of the agenda for governments of developed countries. Few events, amongst which the BSE outbreak and the failure of the WTO Ministerial Conference in Cancun, have been deemed worthy of the front pages of newspapers. It was with the 2008 food crisis that the issues of food security and the fragility of the global food system were brought to the fore as hot topics at the level of governments and international organizations as well as that of society.

The 2008 food crisis and the concomitant financial crisis have shown the contradictions and the shortcomings of neoliberalism to the public at large. Criticism of the system, confined over the previous years at margin of media and academia, have reached the large public and mass media.

In the aftermath of food riots, which spread across poor countries faced by the sudden rise in food prices, two alternative readings of the crisis were given, the "official" one, by mainstream academicians and FAO, and the alternative one, by some ONGs, heterodox social scientists and the various associations which had been fighting the neoliberal food system over the previous years. The comparison of the two analysis offers the opportunity to understand how continuing neoliberal policies may worsen, instead of resolve, future food crisis; it also helps to introduce the discussion on the alternative forms of intervention which is the issue of the next section.

Participants at the FAO Conference held in Rome in June 2008 (FAO, 2008) identified two main causes of the food crisis: 1) the structural changes in demand associated with the high economic growth rate of the emergent capitalistic countries (China in particular); 2) the strong pressure on the energy market, this latter aspect inducing both rising costs of the very fuel dependent food system and a strong competition between food/feed and biofuel crop cultivation. With regards to a third cause, the role of the financial market crisis and its effects on the grain futures market, there was instead a strong disagreement.

In contrast to the "official" interpretation of the crisis, heterodox analysis, as reported by ECT group and PANAP (ECT group, 2008; Guzman, 2008) identified three important points, essential for understanding the food crisis, that were missing in official documents of FAO, national governments and the World Bank (WB). 
The first point was that the food emergency did not emerge overnight, and did not begin with record-high prices. It had already been affecting poor countries for 20 years. In the early 1960s developing countries had an overall agricultural trade surplus approaching $\$ 7$ billion per year (FAO, 2004). By the end of the 1980s the surplus had disappeared and many countries were net importers of food. This shift had been the consequence of US and European policies that had favored corporate agribusiness by keeping commodity prices low, dismantling trade barriers and marginalizing millions of small scale farmers.

The second point was the strong food-financial crisis nexus. The reason for food 'shortages' had been speculation in commodity futures, following the collapse of the financial derivatives markets. Desperate for quick returns, dealers had been taking trillions of dollars out of equities and mortgage bonds and had ploughed them into food and raw materials. The amount of speculative money in commodity futures ballooned from US\$5 billion in 2000 to US $\$ 175$ billion in 2007. This is the 'commodities super-cycle' on Wall Street and its latest illustration has been the post-2008 'land grab' by rich governments and corporations (GRAIN, 2008; Ghosh, 2010; Zagema, Lobbyist, 2011).

The third point, finally, was that whereas shortage of supply had been pointed at as a main cause of the price surge, this might not be the case. Looking at data and forecasts in the period previous to 2008 production outpaced consumption, on average on a two years basis, for all types of food.

Therefore, according to the heterodox interpretation 2008 price rises were driven by the international food trade, notwithstanding the fact that global food trade has been estimated to be only around $10 \%$ of global food production. Because global food trade is controlled by a few TNCs that have gained exceptional profits from price peaks (as reported by Lean, 2008, in the first three month of 2008 Cargill and Archer Daniels Midland increased their net earnings by 86 and 42 per cent) it is likely that high prices have been the consequence, besides the speculation on financial markets, of the exercise of a strong market and buying power by these leading companies.

In other words the heterodox interpretation contends that global food crisis is politicaleconomic in nature and not the mere consequence of unbalanced supply-demand movements. According to this view, the food inflation that has pushed millions of people into poverty and worsened the life of the 2.5 billion people already living on less than $\$ 2$ a day, has been the consequence of: 1) excess of market/buying power exercised by the big corporations of the agribusiness; 2) process of financiarization of the world economy, that has made food commodities markets vulnerable to financial crisis; 3) twenty-five years of lasting neoliberal policies that have worsened inequalities and created food import dependence in less developed countries.

Consistently with the official interpretation of the crisis, FAO, WB and US and EU governments suggested the following prescriptions to cope with the food crisis: further trade liberalization; enhancing agriculture productivity by shifting from smallholders farms to labor-intensive commercial farming; relying on the private sector as provider of agricultural services; promotion of innovation through science and technology; developing high-value markets (i.e. food sold through supermarkets) for domestic consumption; facilitating input markets in order to assure better access to improved seed and fertilizers; improving the land market to facilitate agriculture consolidation processes; enhancing the performance of producer organization to achieve competitiveness of smallholders; linking 
local economies to broader markets and a shift from self-consumption and self-employment to production for the market and to wage employment; investing in safety nets for the poorest people, preferring targeted cash transfers and in-kind food distribution.

Most of these suggested interventions have been criticized by the "heterodox approach" on the grounds that they are likely to continue the commodification of food initiated with the first food regime and then reinforced by the neoliberal agenda in accordance with the Washington Consensus "credo": privatization, liberalization, deregulation, decreasing public social expenditure. As far as these interventions reinforce the true causes of the food crisis, - i.e. corporate power, neoliberal ideology and financiarization- they are unlikely to prevent further future food crisis and promote food security.

As discussed in the following sections, the "heterodox approach", recognizing the limits of the neoliberal project, proposes very different forms of intervention, placing human rights and food sovereignty at a premium.

\section{Building alternatives}

Since its inception, the neoliberal project has been opposed by intellectuals and scholars from the tradition of Marxist research. Nonetheless, it is only since the spread of the antiglobalization movement, in the early 1990s, that critics of neoliberalism have gone beyond the boundaries of leftist intellectual circles and have affected the political arena and society at large. With respect to food-related issues within the antiglobalization movement a large network of non-governmental organizations (NGOs), civil society organizations (CSOs), farmers' organizations and indigenous peoples' organizations have discussed and promoted alternatives to food neoliberal policies. Notwithstanding their diversity and multiplicity, alternatives proposed by different subjects share a common view of the main goals and instruments able to "adjust" the neoliberal model. This common view may be summarized in the following seven points, which form the pillars of the alternative vision:

1. Food as a human right. Food production and distribution is firstly a political matter, secondly an economic matter. Each nation has the duty to uphold this basic human right.

2. Fighting inequalities. Hunger is not the result of limited resources, but rather the effect of unequal wealth distribution and economic injustice.

3. Supporting smallholder farmers. 500 million small farms in developing countries support almost two billion people, nearly one-third of humanity. Nevertheless $80 \%$ of people suffering hunger and malnutrition are food producing households in higher-risk environments $(50 \%)$, herders, fishers, forest-dependent households and non-farm rural household (UNDP, 2003). Therefore supporting small farmers and rural economies is the best way to achieve food security. The case for a massive, government-led investment in smallholder farming and supporting infrastructure is clear.

4. Guaranteeing equal rights to the land, especially of indigenous people and women. Globalization and the internalization of the land market have put the access to land by communities, such as indigenous people, and individuals, such as women, with illdefined property rights and/or low purchasing power at risk. Access to land should be considered as a human right and land should be considered a public rather than a private good. 
5. Food system sustainability. Industrial agriculture, and more generally the whole capitalist economic system, is causing the collapse of earth ecological equilibria. The negative effects of global environmental problems, such as climate change, hit poor people more harshly. Over the coming years, due to climate change, many among the poorest regions in developing countries will face lower agricultural yields. Sustainability is at its core a matter of social justice.

6. Fighting corporate power. Corporate power, as emerged from the processes of consolidation and internationalization of neoliberal globalization, is deemed to be dangerous, in addition to its capability of economic exploitation (through the exercise of market and buying power), because of its lack of responsibility towards society and the environment and because of its power to inform public opinion and capture state regulatory policy. The power-based organizational architectures of commodity chains and the phenomenon of private food governance are outstanding examples of the overwhelming corporate power.

7. Community/state sovereignty opposed to the dictates of WTO, WB and IMF. The opening up of agricultural markets for food imports has put small farmers from developing countries in unfair competition with subsidized farmers from rich countries, destroying production capabilities and worsening the dependence on food imports. WTO jeopardizes government's efforts to sustain agriculture in developing countries, hindering state sovereignty and communities' autonomy.

Table 3 offers an example of the kinds of food policies that opponents to neoliberalism, relying on these principles, sought as viable and effective means to face food crisis. It reassumes, for every "official" proposal of intervention suggested in the aftermath of the 2008 food crisis, the criticism (in terms of alleged corporate advantages and of negative effects on people hit by the crisis) and the counterproposals of the alternative approach.

\begin{tabular}{|l|l|l|l|}
\hline $\begin{array}{l}\text { COPYING WITH } \\
\text { FOOD CRISIS: } \\
\text { NEOLIBERAL } \\
\text { PROPOSALS }\end{array}$ & $\begin{array}{l}\text { CORPORATE } \\
\text { OPPORTUNITIES } \\
\text { FROM NEOLIBERAL } \\
\text { POLICIES }\end{array}$ & $\begin{array}{l}\text { EXPECTED } \\
\text { NEGATIVE EFFECTS } \\
\text { OF NEOLIBERAL } \\
\text { POLICIES }\end{array}$ & COUNTERPROPOSALS \\
\hline $\begin{array}{l}\text { Further trade } \\
\text { liberalization. }\end{array}$ & $\begin{array}{l}\text { New investment and } \\
\text { market opportunities, } \\
\text { accelerating } \\
\text { consolidation } \\
\text { processes. }\end{array}$ & $\begin{array}{l}\text { Expected increases in } \\
\text { economic } \\
\text { inequalities. }\end{array}$ & $\begin{array}{l}\text { Nations should be free to } \\
\text { choose the trade policy, } \\
\text { which better helps to } \\
\text { guarantee the right to the } \\
\text { food, not subject to the } \\
\text { dictates of WTO. }\end{array}$ \\
\hline $\begin{array}{l}\text { Enhancing agriculture } \\
\text { productivity by: } \\
\text { shifting from } \\
\text { smallholders farms to } \\
\text { labor-intensive } \\
\text { commercial farming. }\end{array}$ & $\begin{array}{l}\text { Affirming capitalistic } \\
\text { agriculture as the only } \\
\text { viable way to secure } \\
\text { food. }\end{array}$ & $\begin{array}{l}\text { Smallholder farms } \\
\text { (and women) } \\
\text { negatively affected. }\end{array}$ & $\begin{array}{l}\text { Improving productivity } \\
\text { of small rural farmers } \\
\text { guaranteeing their access } \\
\text { to land, inputs, credit and } \\
\text { "ad-hoc" local } \\
\text { innovations.. }\end{array}$ \\
\hline $\begin{array}{l}\text { Relying on the private } \\
\text { sector as provider of } \\
\text { marketing services, } \\
\text { irrigation, and risk } \\
\text { management services. }\end{array}$ & $\begin{array}{l}\text { New market } \\
\text { opportunities. } \\
\text { Capitalistic control of } \\
\text { public goods. }\end{array}$ & $\begin{array}{l}\begin{array}{l}\text { Poorer farmers } \\
\text { especially women } \\
\text { negatively affected } \\
\text { because of their low } \\
\text { purchasing power. }\end{array} \\
\begin{array}{l}\text { public expenditure in } \\
\text { agricultural extension and } \\
\text { marketing services. }\end{array}\end{array}$ & \\
\hline
\end{tabular}




\begin{tabular}{|c|c|c|c|}
\hline $\begin{array}{l}\text { Promote innovation } \\
\text { through science and } \\
\text { technology. }\end{array}$ & $\begin{array}{l}\text { Widening the market } \\
\text { for the big } \\
\text { agrochemical TNCs. }\end{array}$ & $\begin{array}{l}\text { Devaluation and loss } \\
\text { of local producers' } \\
\text { knowledge and skills } \\
\text { in sustainable } \\
\text { agriculture. }\end{array}$ & $\begin{array}{l}\text { Innovation targeted to } \\
\text { local specificity and able } \\
\text { to treasure traditional } \\
\text { practices and knowledge. }\end{array}$ \\
\hline $\begin{array}{l}\text { Developing the high- } \\
\text { value markets (i.e. food } \\
\text { sold through } \\
\text { supermarkets) for } \\
\text { domestic consumption. }\end{array}$ & $\begin{array}{l}\text { Widening the market } \\
\text { for supermarkets. }\end{array}$ & $\begin{array}{l}\text { Smallholders, as the } \\
\text { poorest people, } \\
\text { would suffer from } \\
\text { higher prices and loss } \\
\text { of local markets and } \\
\text { self-production } \\
\text { opportunities. }\end{array}$ & $\begin{array}{l}\text { Strengthening local } \\
\text { traditional markets. }\end{array}$ \\
\hline $\begin{array}{l}\text { Facilitating input } \\
\text { markets in order to } \\
\text { assure better access to } \\
\text { improved seed and } \\
\text { fertilizers. }\end{array}$ & $\begin{array}{l}\text { Widening the market } \\
\text { for the big } \\
\text { agrochemical TNCs. }\end{array}$ & $\begin{array}{l}\text { Devaluation and loss } \\
\text { of local producers' } \\
\text { knowledge and skills } \\
\text { in sustainable } \\
\text { agriculture }\end{array}$ & $\begin{array}{l}\text { Building local input } \\
\text { markets, improving local } \\
\text { resources and knowledge. }\end{array}$ \\
\hline $\begin{array}{l}\text { Improving the land } \\
\text { market to facilitate } \\
\text { agriculture } \\
\text { consolidation } \\
\text { processes. }\end{array}$ & $\begin{array}{l}\text { Investment } \\
\text { opportunities and } \\
\text { land control by the } \\
\text { richest actors. }\end{array}$ & $\begin{array}{l}\text { Women further } \\
\text { excluded from land } \\
\text { ownership. }\end{array}$ & $\begin{array}{l}\text { Guarantee the right to the } \\
\text { land, especially to } \\
\text { landless farmers and } \\
\text { women }\end{array}$ \\
\hline $\begin{array}{l}\text { Enhance the } \\
\text { performance of } \\
\text { producer organization } \\
\text { to achieve } \\
\text { competitiveness of } \\
\text { smallholders. }\end{array}$ & No effect. & $\begin{array}{l}\text { negative effects for } \\
\text { marginal producers } \\
\text { and landless farmers } \\
\text { because of their lack } \\
\text { of social capital and } \\
\text { land entitlement. }\end{array}$ & $\begin{array}{l}\text { Producers organizations } \\
\text { should operate according } \\
\text { to cooperative behavior, } \\
\text { and oriented to the } \\
\text { preservation of local } \\
\text { market. }\end{array}$ \\
\hline $\begin{array}{l}\text { Linking local } \\
\text { economies to broader } \\
\text { markets and shift from } \\
\text { self-consumption and } \\
\text { self-employment to } \\
\text { production for the } \\
\text { market and to wage } \\
\text { employment. }\end{array}$ & $\begin{array}{l}\text { More opportunities to } \\
\text { exploit labour. }\end{array}$ & $\begin{array}{l}\text { Loss of autonomy of } \\
\text { poor farmers and } \\
\text { more exposure to } \\
\text { harsh exploitation as } \\
\text { workers. }\end{array}$ & $\begin{array}{l}\text { Combining production } \\
\text { for self-consumption with } \\
\text { sales on well functioning } \\
\text { local markets. }\end{array}$ \\
\hline $\begin{array}{l}\text { Investing in safety nets } \\
\text { for poorest people, } \\
\text { preferring targeted } \\
\text { cash transfers and in- } \\
\text { kind food distribution. }\end{array}$ & $\begin{array}{l}\text { Widening the market } \\
\text { for packaged food } \\
\text { (more money spent by } \\
\text { poor people and food } \\
\text { distribution agencies } \\
\text { as new customers). }\end{array}$ & $\begin{array}{l}\text { Less benefits for } \\
\text { women if not } \\
\text { explicitly targeted as } \\
\text { beneficiaries of the } \\
\text { intervention. }\end{array}$ & $\begin{array}{l}\text { Investing in universal } \\
\text { programs of social } \\
\text { security. Avoiding in- } \\
\text { kind food aid, which } \\
\text { advantages vested } \\
\text { interest in donor } \\
\text { countries. }\end{array}$ \\
\hline
\end{tabular}

Table 3. Copying with food crisis: mainstream and alternative proposals

It is worth noticing that many of the arguments of the alternative view, are also acknowledged by the mainstream perspective. For instance, FAO, WB and OCDE have 
produced many studies on issues such as women's access to land, rural poverty, environmental and soil degradation, land grabbing and so on. Recently FAO (FAO, 2009) has also reviewed its traditional claim that high food prices would represent an opportunity for the agricultural sector in developing countries to increase production and raise incomes. Noting that the steady price increases after the 2008 crisis seem not to benefit smallholders, FAO has recognized what the alternative approach has always denounced, namely that smallholders are either engaged in local markets which are not well integrated with the international market, or they suffer from the buying power of distributors, or they lack resources to invest in production increases. Notwithstanding the fact that the "official" and the alternative views to food policy sometimes share the same diagnosis, they nevertheless profoundly differ with respect to the proposed cures and, more importantly, with respect to the economic and political values and credence they rely upon.

In order to understand the acute differences between the mainstream/official and the etherodox/alternative approaches it is helpful to look at the Food sovereignty policy framework, which is one of the more advanced and radical synthesis of alternative food policy view (Windfuhr and Jonsen, 2005; Borras, 2008). Launched at the World Food summit in 1966 by Via Campesina, this program has been endorsed by many organizations and social movements in various fora and international meetings. It is summarized by the Via Campesina's 'Seven Principles to Achieve Food Sovereignty':

1. Food: A Basic Human Right -Each nation should declare that access to food is a constitutional right and guarantee the development of the primary sector to ensure the concrete realization of this fundamental right.

2. Agrarian Reform - A genuine agrarian reform is necessary which gives landless and farming people - especially women - ownership and control of the land they work and returns territories to indigenous peoples.

3. Protecting Natural Resources - Food Sovereignty entails the sustainable care and use of natural resources, especially land, water, seeds and livestock breeds. The people who work the land must have the right to practice sustainable management of natural resources and to conserve biodiversity free of restrictive intellectual property rights.

4. Reorganizing Food Trade - Food is first and foremost a source of nutrition and only secondarily an item of trade. National agricultural policies must prioritize production for domestic consumption and food self-sufficiency. Food imports must not displace local production nor depress prices.

5. Ending the Globalization of Hunger - Food Sovereignty is undermined by multilateral institutions and by speculative capital. The growing control of multinational corporations over agricultural policies has been facilitated by the economic policies of multilateral organizations such as the WTO, World Bank and the IMF. Regulation and taxation of speculative capital and a strictly enforced Code of Conduct for TNCs is therefore needed.

6. Social Peace - Everyone has the right to be free from violence. Food must not be used as a weapon.

7. Democratic control - Smallholder farmers must have direct input into formulating agricultural policies at all levels. Rural women, in particular, must be granted direct and active decision making on food and rural issues. 
It is clear that accepting these principles means to substitute the capitalistic market system, which is the only system envisioned by the mainstream approach, with a mixed economic system where a good deal of resources (for which private property rights might not be allowed) are allocated through state planning and participatory decision mechanisms at local community level, pursuing the objective of social justice before that of economic efficiency. Moreover even the (capitalistic) market sector should be subject to strict regulation in order to prevent concentration and speculation and to stabilize business cycles. In other words at the core of alternative food policy proposals there is the refusal of the capitalistic system as the only viable form of social and economic organization and the presumption that the main institutions of capitalism -private property, market and corporations-, can and must be regulated and limited in their scope when the public good is at stake. Obviously, this is at loggerheads with the mainstream view which instead advocates a worldwide economy and society subservient to the capitalistic accumulation process. And this is the reason why the appeals made by FAO, OCDE, and WB for concepts and goals which partially overlap with those claimed by the alternative approaches, -such as, for instance, the right to the food and to the land, the support to smallholders, market stabilization, sustainability- are more a matter of rhetoric than real programs and commitments. It is a matter of fact that is it not possible to defend the right to the land without genuine agrarian reforms based on redistributive and de-privatization policies, just as it is impossible to stop speculation on commodities without downsizing economic concentration and regulating financial markets. Moreover, in order to sustain local markets it is necessary to renounce to an utter trade liberalization, and to achieve sustainability one needs strict environmental regulations.

In short, since it relies uniquely and completely on the economic standard model, the orthodox food policy approach is unwilling and unable to tackle the problem of justice/equity (social, economic and intergenerational justice), which is at the core of the heterodox approach. Among the three traditional goals of economic policy,-wealth distribution, stabilization of economic cycles and correction of market failures-, neoliberalism is consistent only with the latter. Moreover, it takes as its benchmark pareto efficiency (avoiding any interpersonal wealth comparison) and only admits privatization (according to the Coase theorem) as an instrument to face problems of externalities and public goods, and a Chicagoan competition policy to face market concentration. In contrast, the heterodox approach endorses all the three goals, uses as its benchmark justice/equity and is open to a large array of instruments, consistently with its multidisciplinary attitude.

\section{Obstacles to the implementation of an alternative food policy}

Actually, at the moment, the counter-neoliberal food policy agenda is still a utopia. While many successful experiences of local resistance exist and social movements and heterodox scholars continue to divulgate their programs and principles worldwide ${ }^{3}$, the neoliberal model remains unchallenged, at a political as well as at a cultural level.

Understanding the causes which prevent the counter agenda from prevailing over the old model is essential in order to make food policy move beyond neoliberalism. These causes

\footnotetext{
3 Among the various alternatives it is worth mentioning the Local Economy Movement (Posey, 2011; Mount, 2011) and the agro-ecological project (Horlings, Marsden, 2010).
} 
are both of a theoretical and political nature. Political causes, such as the existence of consolidated centers of political and economic power backing neoliberal policies, have been more or less well investigated by supporters of anti-neoliberalism; nevertheless there is still a lack of suggestions for possible concrete counterbalancing strategies. Theoretical causes have instead received much less attention and this is maybe one of the reasons why the old paradigm is so hard to defeat. In the following part of the paper an effort is made to show the theoretical flaws of the alternative food policy program, first at a general level and then with respect to the two particular issues of food as human right and private food governance.

\subsection{General theoretical obstacles to a counter-neoliberal agenda}

At a general level, the causes of the weakness of the heterodox approach are to be sought in the flaws present in the strands of economic theory which have challenged the standard model so far. Setting aside Marxism, which has developed autonomously, in the seventies, stemming from the criticism of some unrealistic assumptions underlying the neoclassical paradigm - such as informative problems, bounded rationality, non trivial transaction costs, long term and relational contracts, strategic behaviors, path-dependent processes-, many alternative economic theories began to flourish. Over the last forty years many new theoretical approaches have enriched the economic science, among which, to mention just a few: neoinstitutionalism, behavioral economics, bioeconomics, neuroeconomics, evolutionary economics, transaction cost economics, institutionalism, economic sociology, feminist economics, caring economics. All these fields of research are still evolving and there are no unambiguous classifications. However it is generally acknowledged that the neoinstitutional school is the most conservative while institutionalism encompasses nearly all the criticism made of the standard model. In fact institutionalism aims to overcome the rational choice model and the methodological individualism, claiming that in order to understand the complex socio-economic system one should focus on conflicts and power, path-dependency, bounded rationality, historical and cultural dimensions, evolutionary processes, strategic behaviors and network effects. In figure 1, different theoretical approaches (including Marxism and the two approaches in the field of law and politics which have "internalized" the standard economic model, namely the public choice theory and the field of law and economics) are positioned with respect to their consistency with the two opposite neoclassical and institutional frameworks. This figure serves to highlight the main point which is sustained in this paper, that is that the failures of alternative approaches to defeat the hegemony of the standard model - and therefore of neoliberal ideology and policies - depend upon the fact that they have not yet achieved the construction of a new and theoretically consistent, politically acceptable operational model of society (and economy) able to overcome the two key mystifications of the mainstream theory.

The two key mystifications of the standard model refer to its tenet that a market economic system can allocate resources 1 ) without relying on moral values (i.e. ethics does not matter) and 2) without relying on relations of subordination (i.e. power and politics do not matter). A corollary of the second mystification is that a market system can allocate resources in a perfectly decentralized way, without planning and leaders, through an acephalous network of individuals. As a consequence, following the liberal/libertarian tradition à la Nozick, any form of state intervention in the economy is deemed to be useless. 


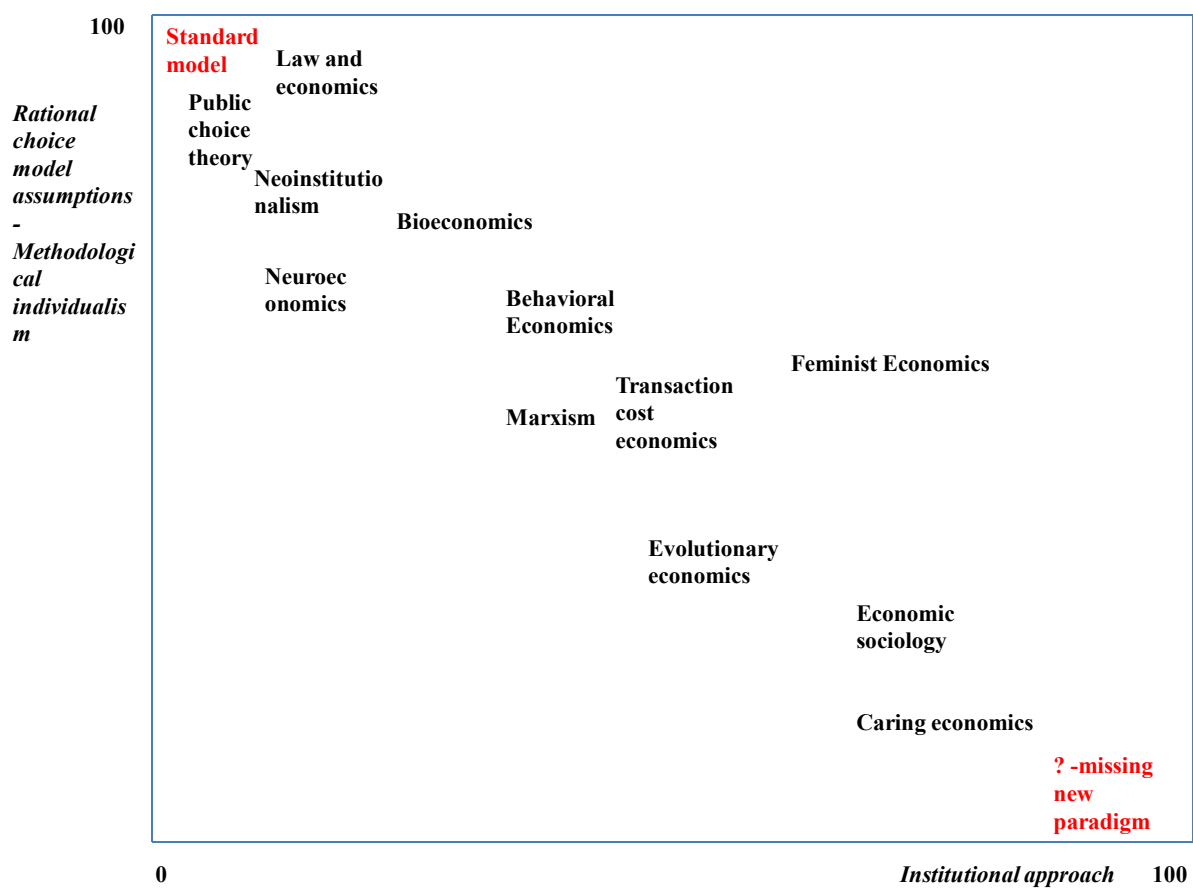

Fig. 1. Alternative economic theories

The first mystification depends on the fact that when claiming that the economic sphere should be independent from value judgments, many defenders of neoliberalism seem to forget that the standard model is completely imbued with ethics; in fact, in order to retain its theoretical consistency, it must subscribe a well defined ethical theory, that is the utilitarianism.

The second mystification is more subtle. Two arguments clearly demonstrate it.

The first argument is taken from the social theory of Coleman (Coleman, 1990) and refers to the legitimization of property rights through power relations. By completely relying on the rational choice theory Coleman, like the economic neoclassical model, assumes exchange and property rights to be the two institutions which are sufficient to have an "ordered" society (as well as an ordered economy) ${ }^{4}$.

Nevertheless, unlike neoclassical economics, which does not question where is the source of property right (it is considered a natural right), Coleman locates the source of property rights in power. When explaining the origin of rights, Coleman says that a right is held by an actor "at the pleasure of the relevant others", where the relevant others are those with the

\footnotetext{
${ }^{4}$ In the Coleman's construction actors are conceived as rational utility maximizing individuals, and resources are conceived as rights. Taking for granted the existence of a legal system of property rights, Coleman notes that when exchanging a resource what really is exchanged are the rights to exercise a certain degree of control over the resource.
} 
power to enforce the right. Coleman explicitly states that "this is a less than fully satisfactory definition because it does not give criteria for determining where the power lies in a specific case. Nevertheless it does locate the source of right in power, where the power itself may be constrained by the prior existence of other rights" (Coleman, p.58) ${ }^{5}$.

The second argument which uncovers the second mystification is based on the evidence that neoclassical theory implicitly relies on a specific political theory, that is contractarianism, which is an extreme form of contractualism. As it is evident in the latest version of neoclassical paradigm, that is neoinstitutionalism, contract is a conceptual artifact that allows to "clean" the economic discourse with regards to the very uncomfortable themes of power and violence. When an economic exchange occurs within a contract voluntarily entered into by counterparties with equal civil and political rights, then any concern about justice and fairness is ruled out and one can concentrate exclusively on the efficiency issue. Instead, as stressed by Pateman, contractarianism not only gives little help in dealing with some basic problems of democracy, but leads to libertarianism, "a political theory that goes hand-in-hand with neo-liberal economic doctrines and global policies of structural adjustment and privatization" (Pateman, 2002). One of the central arguments of Pateman's critique to contractarianism can be synthesized as follows. The starting point is that a real democracy is inconsistent with relations of subordination among citizens. A relation of subordination occurs anytime a person gives another person the right to dispose of her/him. In a relation of subordination the one in power (the master) can command the subordinate to supply services whose outcomes are appropriated by the master. The very example of such a relation is the wage labor contract that is at the core of the capitalist system. Like contratarianism Pateman sees the autonomy of the individual (that is the liberty of choosing "what to do" with her/his person; or put in contractarian terms one can argue that in liberalism the most plausible set of rights is rights of self-ownership) as the basic moral rights on which democratic states must rely. But unlike contractarianism Pateman claims that some kind of contracts that take the form of civil subordination (like the wage labor contract) are inconsistent with the basic moral right of autonomy. To make this point clear Pateman suggests changing the term "self-ownership", generally used in the contractarian theory, for the term "property in the person". When this second term is assumed, it is clear that to say that a person sells, giving others the right to dispose of, some part of her/his person, it is to state an absurdity because the person cannot be divided (the part who sells and the part that is sold) ${ }^{6}$. The term self-ownership obscures this incongruence and legitimizes the "finction of property in the person" on which the contractarian theory is built. In other words, when it is made clear that relations of subordination deny people the enjoyment of their basic right of autonomy, it is also clear that these relations are inconsistent with a true democracy. One consequence of Pateman's

\footnotetext{
${ }^{5}$ It is almost paradoxical that an author like Coleman, who has contributed to make the theory of rational choice the dominant paradigm in social sciences, has in fact helped to highlight one of its the biggest weaknesses, namely the contradiction with the declared libertarian stances and the role of power for the consistency of the entire theoretical edifice.

6 "The idea of property in the person is a political fiction precisely because in practice "agency", "services" or "labor power"-property in the person- are inseparable from the body. But the fiction that what is available as a commodity for sale or rent in the market is merely a piece of property, just like any other, is necessary if such contracts are to be said to constitute free relations." (Pateman, 2007, 210)
} 
arguments is that as long as wage labor contract is at the core of capitalism - this is clearly stated by Pateman and the same idea is stressed by Ellerman (1992) and Screpanti (2001) - a capitalist system is inconsistent with democracy. Therefore, the western model of capitalist liberal economy is an example of "allocation through power" and not through decentralized processes of "free choices" made by "free" economic actors. Moreover, it is clear that when subscribing contractarianism economists end up with reducing their scope of analysis to those problems of resource allocation for which private property rights can be defined, they thus exclude from their analysis all resources for which this is not possible?

Finally, it is worth noticing that utilitarianism and contractarianism are both consistent with methodological individualism, which is the hallmark of the standard model, as well its main limit.

The two analyzed mystifications of the standard model, together with its theoretical elegance, are at the base of its success and of the spreading of the neoliberal ideology. In fact a system which is deemed not to be based on any ethical and political stance finds much less criticism and opposition than one recognizably based on specific values and power relations.

As a consequence of the various arguments given so far, it is now possible to state that an effective alternative proposal to neoliberalism should be able to accomplish the following tasks: 1) to denounce the central mystification of the mainstream economic theory, by demonstrating (as has been just done) that actually neoliberalism is instead imbued with specific ethical and political credos; 2) to demonstrate that the neoliberal ethical and political stances (based on utilitarianism and contractarianism) prevent the system from achieving the goals of general well-being; 3 ) to offer an alternative "credible" (i.e. internally consistent and culturally acceptable) theory able to support (in the sense of furnishing models and frameworks, even weak and flexible models, which help to clarify the rationales and illustrate the possible effects of diverse policies) effective policy interventions. An assessment of the current economic (and social and political) theories alternative to the standard model (and to the rational choice model) with respect to the accomplishment of these tasks is beyond the scope of this paper; nevertheless some rough judgments may be advanced. As drawn in figure 1, only a few alternative approaches have reached a considerable distance from the rational choice model. Let us scrutinize the case of economic sociology. A core element of economic sociology is the acknowledgement of the embeddedness of economic facts in the wider social and institutional environment. As recalled by Smelser and Swedberg $(2005$, p.7) in their masterly introduction to this field of

\footnotetext{
7 The consequences of economists (and economic policies) subscribing contractarianism (or libertarianism, in Pateman's words) are egregiously underlined by Pateman (2007, 212): “Taking contract seriously as a way of ordering social life -contracts all the way down, or social life as an endless series of discrete "origins"- throw light onto trends that have gained pace rapidly since I wrote The sexual contract. The doctrine that all parts of social life and individuals can and should be seen as private property and thus as open to commodification in the market now has global reach. Prevailing domestic and international policy proclaims that everything should be alienable for private profit, from individual "agency" to health care, water supplies, and transport; from animals, seeds, and plant life to genetic materials. All relations should be seen through the lens of contract and private property, so teachers make contracts with pupils, social workers with clients, and governments treat their citizens as consumers of public services rather than citizens who share in decision about, and have a right to, those service."
} 
research, "a major thread in the tradition of economic sociology is that investigation must combine the analysis of economic interests with an analysis of social relations". This thread connects the authors of the classical tradition (Marx, Weber, Durkheim, Simmel) with the renovators (Mauss, Schumpeter, Polanyi, Parsons) and the current field of "new economic sociology", initiated by Granovetter in the mid-1980s. Granovetter gives a very general definition of embeddedness, which states that "economic actions are embedded in concrete, ongoing systems of social relations" (Granovetter, 1985, 487). As shown in the figure 1, economic sociology, due to its premises and methods, partially overlaps with institutionalism and in fact the boundaries between the two approaches are very blurred. None of the two anyway has been able so far to build a consistent alternative paradigm to oppose to mainstream economics. They both have rightly shifted the focus onto the study of institutions and society, but have not offered a consistent theory of these two elements able to overcome the many limits of the rational choice model and methodological individualism. Putting it bluntly, it does not make sense to say that economy is embedded in society if one does not have a clear definition of what society is. In the same way, it is a rhetoric exercise to say that one has to build institutions which serve the general interest while safeguarding individuals' autonomy without having a clear understanding of how structure (institutions) relates to agents. Sociology is still far from resolving these two puzzling problems (i.e the definition of society and the structure/agency relationship), as witnessed by Latour and Archer. Latour, recognizing the inconsistency of previous definitions, seeks to redefine the object of sociological research without "limiting in advance the sort of beings populating the social world" (Latour, 2005, p.16) and conceiving the study of society as the observation of minute associations within a collective. Latour questions the confusion, made by critical sociologists like Durkheim, consisting in replacing the understanding of the social link (which is specifically what Latour maintains should be the scope of sociology) with a political project aimed at social engineering, based on the presumption that society is a special domain of reality ${ }^{8}$. The problem of structure and agency - i.e. the question of how the objective features of society influence human agents and viceversa ${ }^{9}$ - has been faced by Archer throughout her work. Stemming from her previous work on culture and agency (1988) Archer has developed a research program aimed at overcoming the shortcomings of both methodological individualism and collectivism responsible for what she calls the two fallacies of social theorizing, namely 'upwards conflation' and downwards conflation'. In her 1995 book Archer builds a realist social theory (the Morphogenetic Approach) based on a realist ontology of the social world. In her successive works $(2000,2003)$ she specifically addresses the problem of human agency and completes her realist program by

\footnotetext{
${ }^{8}$ Latour is extremely critical of critical sociology, which pretends to explain new social objects (institutions) without investigating on the various elements which form social ties. "Whatever its claims to science and objectivity, critical sociology cannot be sociology - in the new sense that I propose - since it has no way to retool itself to follow through on the non-social elements. When faced with new situations and new objects, they risks simply repeating that they are woven out of the same tiny repertoire of already recognized forces: power, domination, exploitation, legitimization, fetishization, reification.....The problem of critical sociology is that it can never fail to be right." (Latour, 2005, p. 249). 9 "The 'problem of structure and agency' is now familiar phrase used to denote central dilemmas in social theory- especially the rival claims of voluntarism versus determinism, subjectivism versus objectivism, and the micro-versus-macro-scopic in sociology. These issues are central for the simple reason that it is impossible to do sociology at all without dealing with them and coming to decision about them. " (Archer, 1995, p. 65).
} 
reclaiming a notion of humanity and of human subjects endowed with powers of reflexivity. Human power of reflexive deliberation is what gives humans degrees of freedom in determining their own courses of action (Archer, 2003, pp.7-9); personal reflexivity may have real causal powers over structure, it is the missing link in mediation between structure and agency. Even if Archer does not even quote Castroriadis, somehow she addresses the very same "enigma" investigated by this author throughout his professional life, i.e. the possibility of an autonomous society made of free autonomous individuals, instead (and this is the Marxian legacy of Castroriadis intellectual journey) of the heteronomous capitalist (and now neoliberal) society whose members attribute their "ordering imaginaries" to the extra-social authority of self-interest and profit.

\subsection{The case of food as human right and private food governance}

As discussed in previous sections, the concept of food as human right is the milestone of any food policies alternative to the neoliberal project. In article 25 of the Universal Declaration of Human Rights, the human right to adequate food is explicitly recognized as part of the broader human right to an adequate standard of living, with this latter included among economic, social and cultural rights in addition to political and civil rights. Despite the frequent references to the principle of food as human right in the official literature of international organizations, it has never become a normative guide to food security policy (Rae, 2008; Sodano, 2009). For instance, in the US during the last 30 years various groups of scientists and exponents of civil society have proposed making the human right to food the moral and legal cornerstone of US domestic and international initiative in the area of food security, without any success. The U.S. government has consistently opposed formal rightto-food legislation as overly burdensome and inconsistent with constitutional law (Messer, Cohen, 2007). More in general, The U.S. government has repeatedly asserted that economic, social and cultural rights are not part of American legal and political culture, whose liberal ideals would conflict with the agenda requested for the upholding of positive rights.

This is a narrow interpretation of liberal ideals, which hinges upon the unwillingness to question in any way the utilitarian ethics as a normative base for economic policy. It clearly demonstrates the ideological force of neoliberalism, which indeed is a form of ultraliberalism very close to anarcho-capitalism. In fact, it is worth noticing that even in the western liberal tradition, some scholars have argued that the state mandate may be extended to the upholding of positive, besides negative, obligations. This is the case, for instance, of the Human Development Capability Approach (HDCA). HDCA complements the international human right framework by providing normative support for positive obligation and duties (Vizard, 2006), thanks to a definition of liberty that entails a concept of freedom as the range of valuable things that a person can do and be (Nussbaum, 2000). This definition, relying upon ethical principles consistent with Kant's categorical imperatives, goes a far much beyond the definition of liberty given by the classical utilitarianism of classical liberal theories. HDCA stresses that if personal freedom and security are part of the policy aims and if economic (income) and political (freedom) aspects of a person's wellbeing are seen as necessary for assuring basic human capabilities, then state direct intervention for upholding human rights must be accepted. From the consequentialist perspective of utilitarianism what counts is the outcome of the action taken, not the intent of the action. On the contrary, HDCA endorses a deontological ethics, from a Kant's idealistic 
perspective, which insists that intent counts and that policy choices must respect the imperative of "doing the right thing". Embracing an ethical perspective alternative to utilitarianism not only helps to justify the state mandate to uphold positive obligations, it also helps to deal with typical policy choice dilemmas (Pinstrup-Andersen, 2005). When trade-offs exist between different policy options and redistributive problems are at stake (for example: should the well being of poorest children be improved, even when this would lower the total social welfare?) utilitarianism is not useful. This latter point is very important because in the case of food policy many policy actions tend to produce controversial effects; therefore clinging on to utilitarianism greatly narrows the scope of public intervention.

Where the fiction of value-free economic policy (the first mystification) hampers the guarantee of social human rights, the fiction of a market economy as an efficient power-free form of economic organization (the second mystification) hampers the regulatory state capacity and puts equity and democracy in the food system at risk. As highlighted in table 1, food policy neoliberalization has entailed the shift from direct state regulation to private governance (i.e. privatization, self-regulation, CSR), on the grounds that market (which is deemed to coincide with the private sector) is always better than planning (deemed to coincide with the state). That this is actually not the case has been largely clarified by a good deal of literature produced on the issues of private governance and the erosion of state authority due to neoliberal globalization. This literature has demonstrated that waiving of state planning and authority (Strange, 1997) has not entailed a more decentralized and free socio-economic organization but rather an authoritative undemocratic system led by the private planning of TNCs (Hall, Bierstker, 2002), a sort of private international regime (Cutler, 2002). With respect to the food sector, the emergence of private governance has been described through the analysis of the retail revolution and the emergence of third-party certification (Sodano, 2007; Sodano et al., 2008; Clapp, Fuchs, 2009; Van der Meulen, 2011; Fuchs et al. 2011). Conceptualizing the governance of the agrifood system as a field of power struggles between various global and local actors, Fuchs and Kalfagianni (2010) explain the rise of retail private governance on the grounds of structural and ideational power. Structural power refers to the control of material resources (mainly financial means), while ideational sources of power are located in the actor's ability to influence the framing of political issues and to constrain behaviors and actions, drawing on the symbolic meaning of social practices and institutions (Fuchs, Glabb, 2011). Ideational sources of power are particularly important for the legitimisation of private power, which makes retail governance much less likely to be challenged on the basis of concerns over democracy. Assessing consequences of private food regulation, Fuchs and Kalfagianni (2010) conclude that the rise of food retail governance may "have serious consequences for two fundamental attributes of global food governance, namely environmental sustainability and food security...,with the vulnerable and marginalized rural population being the most severely affected groups".

As regards the case of right to food and private governance, both theoretical literature and actions carried out by social movements indicate that many steps forwards in the construction of a counter neoliberal agenda have been already undertaken. Concrete interventions have been suggested and prompted by political protests, such as: agrarian reforms for redistributing land to women and landless rural people; a WTO moratoria for allowing states to pursue independent agricultural policies; a more effective antitrust enforcement for limiting corporate power; public agricultural investments targeted towards 
smallholders; and so on. At least the two tasks of denouncing the mystification of economic theory underlying neoliberal policies and their ineffectiveness in reaching the common well being have been accomplished. Nevertheless, further efforts are needed in order to accomplish the third task, which is to offer a new theoretical paradigm to oppose the rational choice model. It is extremely difficult to outline even just the general features of such a new paradigm. What it is possible to do, instead, is to mention some insights from different theoretical approaches useful for addressing three relevant issues left open by the standard model, namely: 1) how to ethically justify economic (and food) policy; 2) how to solve problems of collective action for the allocation of common pool resources; 3) how to represent a complex system such as the food (and more generally the economic system) system made from the interaction of different human, natural, institutional and technological entities.

In order to address the first two issues, related to moral and collective action problems, it is worth starting by observing that the basic element to go beyond neoliberal food policy is to consider food for community instead of food as commodity, a concept which entails the management of public common pool resources. For these kinds of resources, four kinds of property rights, (setting aside the right of alienation that would entail private property) access, withdrawal, management and exclusion (Olstrom, 2003), must be defined and enforced through collective choice and participatory decision processes aimed at equity besides efficiency. The selfish agents of the rational choice model and the exchange paradigm are incompatible with cooperative collective actions. The feminist scholar Vaughan (1997) has contrasted the exchange paradigm with the gift-paradigm, which emphasizes the importance of giving to satisfy needs. Because the gift-paradigm is needoriented rather than profit-oriented, it precludes the possibility of opportunistic behaviors and free-riding and solves the dilemmas of the classical theory of collective action (Olson, 1971). This paradigm is not utopia because gift-giving is already practiced, but is invisible because goods and services made available for the members of society through it are not accounted for in economic statistics. Mothering, caring, volunteering are all ways of providing goods and services without relying on market exchanges. Similar to the Vaughan concept of giftgiving is the idea of caring economics launched by Eisler (2007). Eislers's starting point is that "we need a new economics", i.e. an economic theory able to help building economic structures that meet human needs. So far neither capitalism nor socialism have proven to accomplish such a task. Eisler notices that the failure of both these economic systems (and their supporting economic theories) is explained by the fact that both have inherited and taken for granted the domination system of patriarchal culture, which may be reassumed into the following typical 'Dominator' economic assumptions: - the main motivations for work are fear of pain and scarcity; - people cannot be trusted; - soft qualities and activities are inappropriate for social and economic governance;- caring and caregiving are impediments to productivity, or at best irrelevant to economics.; - selfishness will lead to the greater good of all. Caring economics calls for a redefinition of economic indicators and measures of welfare in a way so as to take into account not only the wealth produced in the market economy (as it is currently done) but also the wealth produced in the other sectors of the economic system, i.e.: unpaid community economy; household economy; natural economy; government economy; illegal economy (which diminishes welfare). The fundamental change to move towards a caring economics is to substitute the current social and economic relationships based on domination (which is the core trait of patriarchy and 
capitalism, but also of "real" socialist regimes) with relationships based on partnership and cooperative behavior ${ }^{10}$. The giftgiving paradigm and caring economics help to found a new ethics for economic policy, based on the fulfillment of human needs (which is different from personal utility) through cooperative other-regarding behavior. This ethics is grounded in a notion of human subjects who, rejecting both the notions of 'modernity's man and society's being (which in Archer's terminology are the kind of agents featured respectively by the individualistic and constructionist approach of social science), possess the human capacity to transcend instrumental rationality and to have 'ultimate concerns', thanks to the distinctive human power, reflexive deliberation. Reflexive deliberation, i.e. the ability to continuously examine themselves and engage in critical reflection, is what makes individuals autonomous ${ }^{11}$. It is the basis for an autonomous society, where processes of participatory democracy can achieve order without relying on force and power, a "self-instituting" society, in Castroriadis' language, which interprets the ideals of libertarian socialism.

Finally, with regards the third issue let open by the standard model, at the present there are not meaningful suggestions. Interesting insights may come from the ANT program. Whereas an ethics based on the concept of reflexive deliberation helps to integrate moral arguments in policy decision processes and to solve collective choice problems, the analytical/descriptive power of approaches such as ANT, network theory and complex system theory, helps to understand patterns and property of the food system, which is the main field/object where food policies are deployed. In fact, once the ti่ $\mathrm{s}$ of policy has been defined with respect to particular ethical concerns, still remains the problem of choosing effective, besides morally acceptable, tools and strategies of intervention. It is a matter of fact that the food system is a complex system, where the intertwining of natural objects, human beings and technological and institutional artifacts affect the system's properties and performances. Understanding this complex system, its degree of adaptivity, self organization and autonomy, is a conditio sine qua non for designing effective food policies.

\section{Conclusion}

Neoliberalism has produced an unsustainable food system, which might prove inadequate to nourish future generations. Notwithstanding the steady food price increases, natural resources deterioration, loss of resilience of agricultural systems and climate change disturbances, international bodies and national governments continue to propose neoliberal

\footnotetext{
${ }_{10}$ Eisler indicates seven steps to move towards a caring economics 1-Recognize how the cultural devaluation of caring and caregiving has negatively affected economic theories, policies, and practices. 2-Support the shift from dominator to partnership cultural values and economic and social structures. 3-Change economic indicators to give value to caring and caregiving. 4 Create economic inventions that support and reward caring and caregiving. 5 Expand the economic vocabulary to include caring, teach caring economics in business and economic schools, and conduct gender-specific economic research. 6Educate children and adults about the importance of caring and caregiving. 7- Show government and business leaders the benefits of policies that support caring and caregiving, and work for their adoption. ${ }^{11}$ The nexus between reflexivity, autonomy and moral authority is investigated by Bagnoli (2007) in her research on moral objectivity and Kantian intellectual legacy.
} 
policies. Privatization and deregulation are passed off as bulwarks of liberty and efficiency, while they are consigning the system to corporate power and transnational financial elites. All this is made possible not only through the power of organizations with vested interests, but also through the adamant trust of the majority of academics and bureaucrats in the mainstream economics. The paper has explored the way ahead to go beyond neoliberal food policy. The main conclusion is that a viable alternative needs to recognize food as a human right, which implies a shift from the idea of food as commodity to the idea of food for community. It has been demonstrated as well that this shift requires we abandon the particular ethical and political theories underlying the standard economic model, utilitarianism and contractarianism, and look for new theories grounded on the notions of deliberative reflexivity and participatory democracy. Moreover, to design effective alternative policies it is indispensable to foster research in system and network modeling, in order to take into account the complexity and volatility of the system. Research efforts in these fields, together with the political struggles of social movements, are the true challenges for a counter-neoliberal "reloading" of the global food system.

\section{References}

Archer M. (1988). Culture and agency. Cambridge, Cambridge University Press.

Archer M. (1995). Realist social theory: the morphogenetic approach. Cambridge, Cambridge University Press.

Archer M. (2000). Being human: the problem of agency. Cambridge, Cambridge University Press.

Archer M. (2003). Structure, agency and the internal conversation. Cambridge, Cambridge University Press.

Backer, L.C. (2008). Multinational corporations as objects and sources of transnational regulation. ILSA Journal of International \& Comparative Law, 14:2, pp.1-26.

Bagnoli C. (2007). The authority of reflection. Theoria, 22/1, pp.43-52.

Borras S.M. (2008). La Vía Campesina and its Global Campaign for Agrarian Reform. Journal of Agrarian Change, Vol. 8 Nos. 2 and 3, April and July pp. 258-289.

Burch D., Lawrence G. (2009).Towards a third food regime: behind the transformation. Agriculture and Human Values, 26:267-279.

Castroriadis C. (1975). L'imaginaire social et l'institution. Editions du Seuil, Paris.

Clapp J., Fuchs D. ,editors. (2009). Corporate power in global agrifood governance. Cambridge. The MIT Press.

Coleman, J.S. (1990). Foundations of social theory. Harvard University Press.

Cutler A.C. (2002). Private international regimes and interfirm cooperation. In: Hall, Biersteker, editors. The emergence of private authority in global governance. Cambridge University Press.

Eisler R. (2007). The real wealth of nations. Berret-Koehler Publishers, San Francisco.

Ellerman D. (1992). Property and contract in economics: the case of economic democracy. Oxford. Blackwell.

EtcGroup (2008). Who owns nature? Corporate power and the final frontier in the commodification of life. Available at: www.etcgroup.org. 
FAO (2008). Soaring food prices: facts, perspectives, impacts and action required. FAO Conference on world food security, Rome, 3-5 June.

FAO (2009). The State of Agricultural Commodity Markets. High food prices and the food crisis: experiences and lessons learned.

Friedmann H, McMichael P. (1989). Agriculture and the state system: the rise and fall of national agricultures, 1870 to the present. Sociologia Ruralis, 29, 2, 93-117.

Friedmann H. (1987). International regimes of food and agriculture since 1870. In: Shanin T.,ed., Peasants and peasant societies. Oxford: Basil Blackwell, 258-76.

Friedmann H. (1993). The political economy of food: a global crisis. New Left Review January-February I/197, 29-57.

Friedmann H.(2004). Feeding the empire: pathologies of globalized agriculture. In: Panitch L. and Colin Leys, ed., The empire reloaded, London.

Fuchs d., Glaab K. (2011). Material power and normative conflict in global and local agrifood governance: the lesson of Golden Rice in India. Food Policy, in press.

Fuchs D., Kalfagianni A. (2010). The causes and consequences of private food governance. Business and Politics, 12, 3, 1-25.

Fuchs D., Kalfagianni A., Havinga T. (2011). Actors in private food governance: the legitimacy of retail standards and multistakeholder initiatives with civil society participation. Agriculture and Human Values, 28:353-367.

Garnett, T. (2008). Cooking up a storm. Food Climate Research Network.

Ghosh J. (2010). The unnatural coupling: food and global finance. Journal of Agrarian Change, 10, 1, January, pp. 72-86.

GRAIN (2008). Seized! The 2008 Land grab for food and financial security. GRAIN briefing, October.

Granovetter M. (1985). Economic action and social structure: the problem of embeddedness. American Journal of Sociology, 91:481-93.

Guzman, R.B. (2008). The global food crisis: hype and reality. PANAP, July, issue no. 7.

Hall R.B., Biersteker T.J. (2002). The emergence of private authority in global governance. Cambridge University Press.

Harvey, D. (2005). A brief history of Neo-liberalism. Oxford University Press.

Latour B. (2005). Reassembling the social: an introduction to Actor-Network-Theory. Oxford, Oxford University Press.

Lean, G (2008). Multinationals make billions in profits out of glowing global food crisis. The Independent, Sunday, 4 may.

McMichael P. (2009). A food regime genealogy. The Journal of peasant Studies, 36-1, 139169.

Messer, E. and Cohen, M.J. (2007). The human right to food as a U.S. nutrition concern 19762006. IFPRI Discussion Paper 00731.

Mount P. (2011). Growing local food: scale and local food systems governance. Agriculture and Human Values, published online.

Nussbaum M. (2000). Women and human development, Cambridge University Press.

Olson M. (1971) [1965]. The Logic of Collective Action: Public Goods and the Theory of Groups (revised edition). Harvard University Press. 
Ostrom E. (2003). How types of goods and property rights jointly affect collective action. Journal of Theoretical Politics. 15 (3) 239-270.

Pariotti E. (2009). International soft law, human rights and non-state actors: towards the accountability of transnational corporations? Human Rights Review, 10, pp.139155.

Pateman C (2002). Self-ownership and property in the person: democratization and a tale of two concepts. The journal of political philosophy, 10, 1 20-53.

Pateman C., Mills C. (2007). Contract and domination. Polity Press.

Pechlaner G., Otero G. (2010). The Neoliberal Food Regime: Neoregulation and the New Division of Labor in North America. Rural Sociology 75, 2:179-361.

Pinstrup-Andersen P. (2005). Ethics and economic policy for the food system. American Journal of Agricultural Economics, 87, 5, 1097-1112.

Rae, I. (2008). Women and the right to food, FAO, http:/ / www.fao.org/righttofood.

Posey J. (2011). The local economy movement: an alternative to neoliberalism?. Forum For Social Economics, 40:299-313.

Sassen S (1995). Losing control? Sovereignty in an age of globalization. Columbia University Press.

Sassen S. (2006). Territory, authority, rights. Princeton University Press.

Shiva, V. (2008). Soil not oil. South End Press.

Smelser N.J., Swedberg R. (2005). Introducing economic sociology. In: The handbook of economic sociology, edited by Smelser N.J.and Richard Swedberg. Princeton, Princeton University Press.

Sodano V. (2007). Food safety and social capital: a double side connection. In: Fritz M., Rickert U., Schiefer G. (eds.) System Dynamics and Food Networks Research. Bonn -ILB Press. pp.75-92.

Sodano V. (2009). Food insecurity, Human rights, and gender inequalities. In: Miller K., Hobson West P., Nerlich B. Ethical futures: bioscience and food horizons, Wageningen academic publishers.pp.291-296.

Sodano, V., Hingley, M., and Lindgreen, A., (2008). The usefulness of social capital in assessing the welfare effects of private and third-party certification food safety policy standards: trust and networks. The British food Journal, 110: 493-513.

Stigler G. (1971). The Theory of Economic Regulation. Bell Journal of Economics, 2, 3-21.

Strange S. (1996). The retreat of the state: the diffusion of power in the world economy. Cambridge, Cambridge University Press.

Strange S. (1998). Mad money. University of Michigan Press.

Van der Meulen B., editor (2011). Private food law. Governing food chains through contract law, self-regulation, private standards, audits and certification schemes. Wageningen Academic Publishers.

Vaughan G. (1997). A feminist criticism of exchange. Plain View Press, Austin.

Vizard, P. (2006). The HDC Approach and human rights. Human and Development and Capability Association, briefing note. Available at:

http:/ / www.capabilityapproach.com.

Windfuhr M., Jonsen J.(2005). Food Sovereignty: Towards democracy in localized food systems. Practical Action Publisher. 
Zagema B., Lobbyist S. (2011). Land and Power. The growing scandal surrounding the new wave of investments in land. Oxfam. 


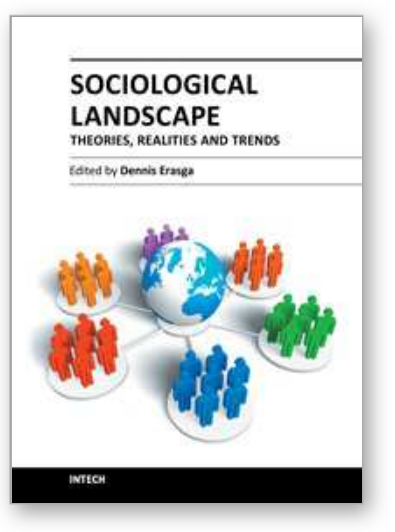

\author{
Sociological Landscape - Theories, Realities and Trends \\ Edited by Dr. Dennis Erasga
}

ISBN 978-953-51-0460-5

Hard cover, 428 pages

Publisher InTech

Published online 28, March, 2012

Published in print edition March, 2012

More than the usual academic textbook, the present volume presents sociology as terrain that one can virtually traverse and experience. Each version of the sociological imagination captured by the chapter essays takes the readers to the realm of the taken-for-granted (such as zoological collections, food, education, entrepreneurship, religious participation, etc.) and the extraordinary (the likes of organizational fraud, climate change, labour relations, multiple modernities, etc.) - altogether presumed to be problematic and yet possible. Using the sociological perspective as the frame of reference, the readers are invited to interrogate the realities and trends which their social worlds relentlessly create for them, allowing them in return, to discover their unique locations in their cultures' social map.

\title{
How to reference
}

In order to correctly reference this scholarly work, feel free to copy and paste the following:

Valeria Sodano (2012). Food Policy Beyond Neo-Liberalism, Sociological Landscape - Theories, Realities and Trends, Dr. Dennis Erasga (Ed.), ISBN: 978-953-51-0460-5, InTech, Available from:

http://www.intechopen.com/books/sociological-landscape-theories-realities-and-trends/food-policy-beyondneo-liberalism-looking-for-a-new-paradigm-through-the-lens-of-economic-sociology-

\section{INTECH}

open science | open minds

\section{InTech Europe}

University Campus STeP Ri

Slavka Krautzeka 83/A

51000 Rijeka, Croatia

Phone: +385 (51) 770447

Fax: +385 (51) 686166

www.intechopen.com

\section{InTech China}

Unit 405, Office Block, Hotel Equatorial Shanghai

No.65, Yan An Road (West), Shanghai, 200040, China 中国上海市延安西路65号上海国际贵都大饭店办公楼 405 单元

Phone: +86-21-62489820

Fax: +86-21-62489821 
(C) 2012 The Author(s). Licensee IntechOpen. This is an open access article distributed under the terms of the Creative Commons Attribution 3.0 License, which permits unrestricted use, distribution, and reproduction in any medium, provided the original work is properly cited. 